14h - 15h30 | Aug. 24, 2017 - Thursday | ROOM 16

\title{
THE COMMUNICATION OUTLOOK FOR THE FUTURE OF BROADCASTING AND NEW
} MEDIA

\section{Chair: Prof. Doutor Fernando Carlos Moura - Editor-in-chief of SET Magazine}

In this session, Brazilian Communication scholars will have the opportunity to analyze the changes in the audiovisual production chain, with an emphasis on content distribution and how the behavior of the audience is changing in the face of new consumption demands, both in audiovisual and radio. Will be analyzed the new platforms of audiovisual distribution by streaming, whether VoD or OTT, and the new tools of content delivery. This is a unique opportunity to exchange experiences with those who provide the support and tools for producing and distributing content.

- THE POSSIBILITIES OF MULTIPLATFORM RADIO CONTENT Speaker: Prof. Me. Alvaro Bufarah - Coordinator of the Post-Graduate Course in Executive Production and TV Management at FAAP.

The purpose of the exhibition is to present the various aspects of the impact of new technologies on Brazilian radio stations, analyzing the various forms of access to radio content on digital platforms, as well as differences among consumers.

- TV UNESP AS SPACE OF CREATION AND LABORATORY FOR INNOVATIONS IN TELEVISION TECHNOLOGY

Speaker: Prof. Dr. Francisco Machado Filho - Professor of Journalism / UNESP Bauru

With five years on the air Unesp TV has been consolidating itself as a space for testing formats of programs and technological innovations that are impacting Brazilian broadcasting and imposing important challenges for private or educational broadcasters. In this session we will present the ways the radio station has come to face this moment of technological convergence and reaffirm the SET /TV Unesp partnership for the coming years. 
- CHANGE IN AUDIOVISUAL CONSUMPTION

Speaker: Prof. Me. Renato Tavares Junior - professor - Anhembi Morumbi / Cásper Líbero

Discussion on the study of the strategies of self-promotion and placement of contents and formats produced by TV stations in a multi-platform environment and digital convergence.

- TELEVISION PROGRAMMING DELIVERY (OTT) AND LINEAR TV Speaker: Prof Dr. Willians Cerrozi Balan - Professor of the Unesp Radio and TV Course

Digital platforms have changed the behavior of the viewer in relation to the ways of watching TV. How will (linear) TV broadcasters react to keep the audience?
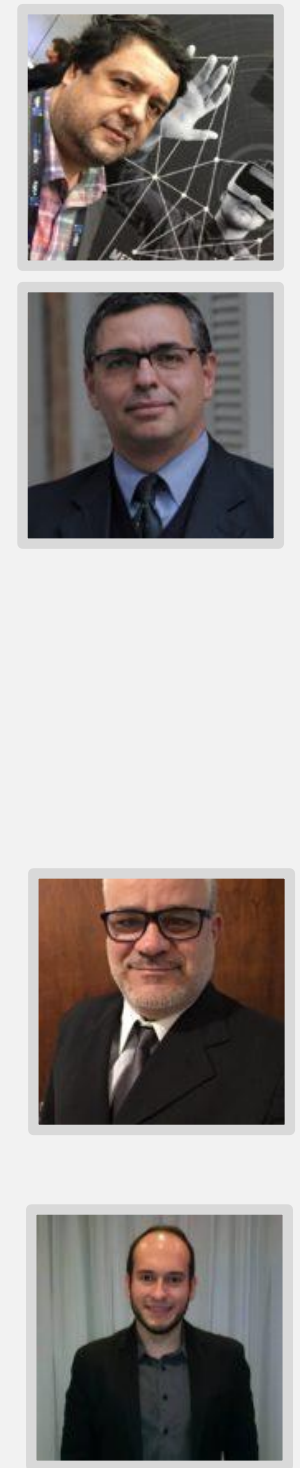

Prof. Me. Renato Tavares Junior - professor - Anhembi Morumbi / Cásper Líbero

Coordinator and professor of the course of Radio, TV and Internet of the University Anhembi Morumbi. Professor of Journalism, Advertising and Radio, TV and Internet courses at Cásper Líbero College. Idealizer and professor of the Postgraduate course in Strategies of TV Programming of the University Anhembi Morumbi. Bachelor in Radio and Television and Master in Communication Sciences from ECA-USP. PhD in Audiovisual Communication from Anhembi Morumbi University. 


\section{Prof Dr. Willians Cerrozi Balan - Professor of the Unesp Radio and TV Course}

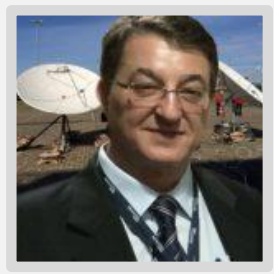

Graduated in Music from USC, a Master's in Visual Poetics from Unesp, and a Doctorate in Digital TV from the Methodist University of São Paulo. Professor on the Radio and TV course at Unesp in the subjects of Radio and TV Management, Photography Direction, TV Program Direction and Organization of Production among others. He worked at TV Globo in the Production, Engineering and Journalism areas, and at TBR Produções in advertisement production, videos and Distance Learning. He has experience in live transmissions via satellite and the internet. Internationally, he was involved in transmitting the FIFA World Cup, the Olympic and the Pan American Games, among others. 